\title{
Study of the amount of Human Resources Architecture Archetype application at University of Isfahan
}

\author{
Raziyeh Yosof Boroujerdi (Corresponding author) \\ Dept. of Educational Administration, University of Isfahan. \\ Isfahan, Iran \\ Tel:98 -311-7932509Ｅ-mail: ryosof@gmail.com \\ Seyed Ali Siadat. Ph.D \\ Dept. of Educational Administration, University of Isfahan. \\ Isfahan, Iran \\ Reza Hoveida. Ph.D \\ Dept. of Educational Administration, University of Isfahan. \\ Isfahan, Iran
}

Received: June 10, 2013 Accepted: June 19, 2013 DOI: 10.5296/jpag.v3i2.3982

\begin{abstract}
Each organization needs specific Human capital which have high unique and strategic value creation .Hence, human resources management of organizations must comply itself with these key people. So, it is clear that organizations in order to gain competitive advantage, must focus on this most important factor, human resources. This has a strategic role in Excellence of organizations. This research is focused on human resources architecture. Therefore, the purpose of this article was to study the amount of application of the Human Resources Architecture Archetype dimensions, Human Resources practices at University of Isfahan Research method was Descriptive and statistical, population includes all faculty members at University of Isfahan (561 people) in academic year 2011-2012.Sample size using stratified random sampling proportionate to volume was estimated at 231 people. Data collection tool was a researcher made questionnaire designed based on the five-point Likert scale. Its reliability coefficient using Cronbach's alpha was calculated 0/80.And data analysis was performed by using SPSS statistical software. Findings of human resources architecture archetype at the University of Isfahan is less than average.
\end{abstract}

Keywords: Human resources architecture, Human Resources Practices, Human capital 


\section{Introduction}

Human Resource Architecture is one of the three types of Enterprise Architecture. (Wydra, 2005).This perspective considers the organization as a physical structure that can have non-physical dimensions.(Samadi,2007).As there should be close relation between the fundamental elements of a structure and its application and uses, there should be coordination among the fundamental elements of an organization, objectives and its mission. (Jap, 2004) .Enterprise Architecture is an organizational plan which explains the mission structure and required information of the organization and necessary technology to support them. (CIO Council., 2001). The topic of architecture human resources is employment relationship with organization and then the formation and implementation of human resources management based on these relationships in the organization. Employment relations are formed based on knowledge orientation and strategic value of individuals to an organization. (Lepak $\boldsymbol{d}$ Snell, 1999). In every organization there is a set of connected outcomes which affect the control of human behavior. Some of these outcomes there are in the official policies, programs or procedures. But many of them are non-written part of organizational culture.This set of connected results can be called the human resources architecture of organization.

Human resource practices usually are defined based on an organization's human resource policies. And in a larger organization, components of human resources architecture probably are more organized and more structured .But what is documented, often does not reflect the real outcomes that followed by the employees behavior. And contrary to what employees are express. destructive behavior is reinforced in an orderly way, while good behavior is punished in an organized manner. For example, people are told to have innovations, but when they do things differently, they are reprimand or blamed. Employment relationship between organization and employees represent a transactional one. The exchange is a contract between an organization or individual and organizations or other person that are based on limited rationality and opportunity.

\section{Review of research literature}

Human resources architecture is a new field in the human resource management literature. That its purpose is to draw the human aspects of organization and accentuate the role of key staff in implementation of organization's mission and strategies. Thus, in terms of theoretical literature, there is not much resources about it. But ,since it has roots in present theories, and theoretical patterns, effort has been done to examine the roots, principles, related theories, and the main origin of these patterns in this area. Beaty and Huselid (2007) in a research titled "A new measurement tool for human resources: Scoring based on the balanced score card "specify four components in the human resources architecture, and examine the relationship among them. The results of their studies indicate that knowledge, expertise and skills are the indicators of the competencies of human resources, that had a positive effect on the indicators of human resources practices, such as: communication, job design, selection, rewards, staffing and training, development. Similarly, human resources practices had a significant effect on human resources system (aligned construction, integration, desegregation) that may lead to the achievements of human resources outcomes. 
Kinnie and Swart (2006) in their study titled "The relationship between human resources procedures and reconstruction of strategies in the creative organization ", concluded that the reconstruction strategies, has a positive impact on human resources procedures, which ultimately will lead to satisfactory performance.

Chew (2004) in his study titled "Effect of human resources management procedures on retention of main staff" in Australia concluded that there is a significant relationship between competencies and achievements of human resources.

Kang (2003) developed the initial model of Lepak and Snell, and designed a model called relational architecture model, which it is product of cognitive, emotional and structural relationship among knowledge oriented workers in organization.

This study specified that all staff, based on their human capital, don't participate in a similar manner. Second, different arrangements of human resources are used in organizations for different skill groups, and third, the creation of value and strategies are the product of human capital compounds among different categories of individuals.

Lepak and Snell (2002) in their study examined the relationship between human capital characteristics and employment conditions. They considered human capital as the main source of value creation and determining organizations assets. They presented a conceptual model of human resource architecture based on unique and strategic value of human capital which consists of four components: knowledge-oriented employment, job-oriented, contract work arrangements and partnership. That in human capital, it has direct relationship with first component and it has inverse relationship with the third component and it has a significant relationship with other two components. In general, limited studies have been done about human resources architecture pattern in the world, especially desired model.

Because dealing this issue significantly has a positive effect on organizational function, and organizational restructuring, but it has been neglected from researchers of human resources and organizations, So what distinguishes this study from other researches is using this model in higher education that can improve productivity and effectiveness of human capitals in higher education in general, and specifically at University of Isfahan.

\section{Research method}

This study in terms of purpose is practical and in terms of method, is descriptive. Because in this study, researcher deals with describing the amount of application of human resources architecture pattern at University of Isfahan. Statistical population of this study consisted of all faculty members of University of Isfahan totaled 561 people in the academic year 2011-2012. In this study, for sampling, Stratified sampling proportional to size of population is used. Therefore, among the faculty members of University of Isfahan, 231 individuals were selected using Morgan Table. Then, the questionnaires were distributed randomly among them. Therefore in this study, data were collected using a researcher made questionnaire. Expert and the manager opinions and Cronbach's alpha coefficient formula were used to assess the validity and reliability of questionnaire. Collected quantitative data of the study was analyzed using appropriate and necessary descriptive statistical indicators (mean, Percentage, variance, standard deviation, etc.) and inferential statistics using SPSS software. 


\section{Ml Macrothink}

\section{Findings}

Table (1) - Distribution of faculty members based on sex.

\begin{tabular}{|l|l|l|}
\hline & frequency & percentage \\
\hline Female & 37 & $16 / 0$ \\
\hline Male & 194 & $84 / 0$ \\
\hline Total & 231 & 100 \\
\hline
\end{tabular}

Based on above table, only $16 \%$ of faculty members are women and this figures show that the proportion of women to men is almost 1 to 5 .

Table (2): Distribution of faculty members based on age.

\begin{tabular}{|l|l|l|}
\hline & frequency & percentage \\
\hline $20-30$ years & 20 & 8.7 \\
\hline $31-40$ & 87 & 37.7 \\
\hline $41-50$ & 85 & 36.8 \\
\hline $50-60$ & 33 & 14.3 \\
\hline 60 and above & 6 & 2.6 \\
\hline total & 231 & 100 \\
\hline
\end{tabular}

Based on information in the table (2), the least respondents were in the range of 60 years and above of age category while the most respondents belong the category of 31-40 years old.

Table (3)- Distribution of faculty members based on level of education.

\begin{tabular}{|l|l|l|}
\hline & frequency & percentage \\
\hline Master & 16 & 6.9 \\
\hline PH.D. & 215 & 93.1 \\
\hline Total & 231 & 100 \\
\hline
\end{tabular}

Based on information in the table (3), most of faculty members $(93.1 \%)$ have a doctorate degree, which is fairly good. 
Table (4) - Distribution of faculty members based on years of service.

\begin{tabular}{|l|l|l|}
\hline & frequency & percentage \\
\hline Under5years & 94 & 40.7 \\
\hline $5-10$ & 32 & 13.9 \\
\hline $11-15$ & 20 & 8.7 \\
\hline $16-20$ & 49 & 21.2 \\
\hline 20 and more & 36 & 15.6 \\
\hline Total & 231 & 100 \\
\hline
\end{tabular}

Based on information in the table (4), it can be argued that most of faculty members (40.7percent) belong to category that have 5 or less year of service and are young body of university.

Table (5) - Distribution of faculty members based on employment status.

\begin{tabular}{|l|l|l|}
\hline & frequency & percentage \\
\hline Tenure & 109 & 47.2 \\
\hline Contractual & 122 & 52.8 \\
\hline Total & 231 & 100 \\
\hline
\end{tabular}

Based on information in the table (5), it can be concluded that a significant portion $(52.8$ percent) of faculty members do not have job security and are not tenure.

Table (6) - Distribution of faculty members based on academic ranking.

\begin{tabular}{|l|l|l|}
\hline & frequency & percentage \\
\hline Mentor & 24 & 10.4 \\
\hline Assistant Prof. & 170 & 73.6 \\
\hline Associate Prof. & 33 & 14.3 \\
\hline Full Prof. & 4 & 1.7 \\
\hline Total & 231 & 100 \\
\hline
\end{tabular}

information in table (6), reveals that significant number(170 out of 231) or $73.6 \%$ of faculty member are assistant professors and this is in support of table (4) that showed most of faculty 
members do not have much years of academic service.

Table(7)- comparison of grade averages for application of human resources practices indicators of human resources architecture model(communication. training and development. job design, recruiting, reward) at university of Isfahan, with hypothetical average of 3.

\begin{tabular}{|l|l|l|l|l|}
\hline & Average & Standard deviation & Standard error & $\mathrm{t}$ \\
\hline Human resources practices & 2.89 &.$/ 588$ &.$/ 038$ & $-2 / 77$ \\
\hline
\end{tabular}

Based on information in table (7), it can be concluded that observed $t$ is less than critical level at $\alpha \leq 00.5$; therefore amount of application of human resources activities at university of Isfahan is less than average level.

\section{Discussion and Conclusion}

Many environmental factors in human resources architecture are considered that influence organization mission and strategies (Wright \& snell, 1998). Consistency between mission and strategies whit human resources is vital for successful implementation of organizational goals (Schuler \& Randall.2006). This is not possible unless human resources are managed through strategic management in this approach, those can implement organizational missions who possess commitment, knowledge and expertise. Proper strategies for increased participation are designed through strategic management of human resources. Factors that affect human resources architecture are environmental changes that act as prerequisite for determining strategies and technology of organization (Shams.1996). Human resources architecture approach considers employees as an important capital. Human capital management is a developed concept of human resources management with direction of value added (Nelson, 2004), Hietala (2006) and Baron(2008) consider human capital as one of the organizations' intangible capital like social capital, intellectual capital and organizational capital. Human capital is preserved knowledge, skills and abilities that can potentially help increase productivity and performance (Hietela, 2006). On this basis, human capital management is activities, processes, and systems that are used for management and staff development. Therefore, to limit employee in a pre-determined framework called "Job" can decline the productivity of this basic capital ((Menzies and Lyer, 2004). Barney (1991) argues that managers should consider their human resources as an organizational cost. Here human resources are defined as a set of knowledge and expertise and irreplaceable social relations which are the main source for organizational competitive edge.

\section{Suggestions}

- Human resources architecture, within university, is considered as an independent unit.

- Distinguishing human side of organization through recruiting knowledge-oriented and specialized employees.

- In employment process, every activity should emphasize organizational mission and 
goals.

- Training and staff development be updated.

- Activities are value added.

\section{References}

Samadi, A. A .(2007). Introduction to Enterprise Architecture (to managers), Tehran, Supreme Cultural Revolution Council.

Barney, J. B. (2001). Is the resource-based "view" a useful perspective for strategic management research? Yes. Academy of Management Review, 26(1): 41-56.

Barney, J. B. (1991): Firm Resources and Sustained Competitive Advantage, Journal of Management, 17(1): 52-63.

Beaty, R W \& Huselid, M A. (2007): New HR Metrics: Scoring on the Business Scorecard, Chapter 16 from Strategic Human Resource Management.14, 355-357.

Chew, J (2004): The Influence of Human Resource Management Practices on the Retention of Core Employees of Australian Organization: an Emerical Study, Thesis of Doctor of Philosophy, Murdoch University.

Chief Information Officer Council (CIO), (2001): A Practical Guide to Federal.

Hietela, K (2006): General Framework for Long -Term Social Impact Evaluation of an Employment Strategy Sub-reports: Human Capital, USA, Ministry of Labour.

Japp, S (2004): Enterprise Architecture Source Card, London, Institute for Enterprise Architecture Development.

Kang, S., \& Morris, S., Snell, S. A. (2003). Relational archetypes, organizational learning, and value creation: Extending the human resource architecture. Working paper: CAHRS, Cornell University.

Kinnie, N., \& Swart, L(2006).The Link Between HR Practices and Strategic Renewal in Creative Organizations: organizational learning and knowledge related performance, both at the Work and Employment Research Center (WERC),London, School of Management, University of Bath, BA2 7AY,UK.

Kordestani, G. R. (2008), Measurement and reporting of human capital, Hesabras journal, 41: $32-26$.

Lepak, D. P., \& Snell, A., \& Scott, A. (2002): Examining the Humane Resource Architecture: The Relationships Among Human Capital, Employment, and human Resource Configurations, Journal of Management, 28(4).

Lepak, D. P., \& Snell, A., Scott. A. (1999). The human resource architecture: Toward a theory of human capital allocation and development. Academy of Management Review, 24(1): $31-48$. 


\section{Macrothink}

Journal of Public Administration and Governance ISSN 2161-7104 2013, Vol. 3, No. 2

Lyer, S. (2004): Human Capital Management, Peyote Morgan Associates, Nandaki Management System Pvt.Ltd.

Menzies, 1(2003): Unlocking the human Potential for Public sector Performance, Expert Group Meeting, United Nations. Florence. Italy, May6, 2006.

Nelson, R. E. (2004). The strength of strong ties: Social networks and intergroup conflict in

Organizations. Academy of Management Journal, 32: 377-401.

Saraee, H. (2003). Introduction to sampling in Research, Third edition, Tehran: Samt Publication.

Schuler, R. S., Randall, M., (1992). Strategic human resource management: Linking people with the needs of the business. Organizational Dynamics, 22: 19-32.

Williamson, O. E. (1971). Markets and hierarchies: Analysis and antitrust implications. New York: Free press.

Wright, P. M., \& Gardner, T. M. (2003). Theoretical and empirical challenges in studying the HR practice - firm performance relationship. New York, Hamilton.

Wright, P. M., \& Snell, S. A. (1998). Toward a unifying framework for exploring fit and flexibility in strategic human resources management. Academy of Management Review, 23(4): 756-772.

Wydra, F, T.(2005).Human Resources Architecture, Consultants to Management Inc, Michigan, USA.

\section{Copyright Disclaimer}

Copyright reserved by the author(s).

This article is an open-access article distributed under the terms and conditions of the Creative Commons Attribution license (http://creativecommons.org/licenses/by/3.0/). 